\title{
Drivers of Indian Naval Expansion
}

\author{
Walter C. Ladwig III \\ in Harsh V. Pant (ed.), The Rise of the Indian Navy: Internal Vulnerabilities, External \\ Challenges (Ashgate 2012), pp. 19-40.
}


Traditionally the neglected 'Cinderella' service of the Indian armed forces, the Indian Navy is in the midst of a modernization programme that has attracted international concern from commentators who worry that this might pose a risk to stability in the Indian Ocean or presage a naval arms race in Asia. ${ }^{1}$ This chapter attempts to understand what is driving this uncharacteristic focus on the Navy, concentrating on developments in the 20-year period since the end of the Cold War (1991-2011). The analysis proceeds in two parts. The first section examines several different measures, including number of ships, aggregate tonnage, number of missile cells and budgetary allocation to understand the trajectory of the Indian Navy over the past 20 years. Section two examines three oft-cited justifications for naval expansion - defence against hostile maritime powers, the cultivation of power projection capability to further India's political interests, and the protection of trade - in relation to the fleet's actual platform acquisitions to determine their relative importance in driving naval development.

The available data suggests that the primary mission driving naval modernization is sea-lane security, with the development of 'softer' aspects of power projection capability receiving some support, while the need to deter hostile maritime powers does little to explain India's recent naval modernization. This focus on enhancing India's ability to provide

\footnotetext{
${ }^{1}$ On the Indian naval modernization generally, see Anand Giridharadas, 'India is Projecting its Military Power', New York Times, 22 September 2008; Bruno Alexander de Paiva, 'India's Naval Modernization Program', Jakarta Post, 23 May 2011. South Asian commentators expressing concern about the Indian navy include Md. Khurshed Alam, 'Expansion of the Indian Navy', Daily Star (Bangladesh), 16 June 2007; 'Indian Military Growth Threatens Regional Stability', Agence France-Presse, 26 February 2010; Syed Jafar Askari, ‘Growth in Indian Navy Matter of Concern', The Nation (Pakistan), 2 June 2010; and Masood-Ur-Rehman Khattak, 'Indian Military's Modernisation: A Threat To Strategic Stability Of South Asia', Eurasia Review, 26 March 2011. For concern about a naval arms race in Asia, see Robert Kaplan, 'Lost at Sea', New York Times, 21 September 2007; 'Chasing Ghosts', The Economist, 11 June 2009; Edward Wong, 'As Chinese Navy Extends Reach, Pacific Governments Grow Uneasy', New York Times, 15 June 2011.
} 
regional 'public goods,' such as sea-lane security and humanitarian response, strongly suggests that this growing naval strength can emerge as a net positive for the region. [19]

\section{Is the Indian Navy Growing?}

Despite the international attention given to the Indian Navy's recent acquisitions, some observers argue the fleet is actually withdrawing platforms faster than it is adding them. ${ }^{2}$ In an effort to clarify this situation, three different measures are used to judge developments in the fleet since 1991: number of ships, size of ships and the number of missile cells per ship. To understand whether this observed naval modernization is evidence of a determined turn to the sea on the part of the Indian armed forces, a fourth measure, relative budget share, is also examined. Collectively, these measures suggest the Navy is acquiring significantly more advanced platforms, while the overall number of ships is relatively static, but this does not indicate a reprioritization of the Navy vis-à-vis the other armed forces.

The most obvious way to measure growth is to count the number of ships in the fleet. In terms of major [20]platforms - submarines, principal surface combatants (aircraft carriers, destroyers and frigates) and amphibious ships - the Indian Navy has slightly contracted over the last 20 years. The fleet possessed 51 major vessels in 1991, but only 50 such ships today. ${ }^{3}$ During this period, the Navy lost submarines, frigates and aircraft carriers, while gaining destroyers and amphibious warships. [21]

\section{Figure 2.1 Indian naval strength: 1991-2011}

Since quality matters as well as quantity, the number of ships alone is not a sufficient measure of the health of a fleet. In the absence of a detailed analysis of the weapons, radars and

\footnotetext{
${ }^{2}$ Analysts suggesting the Indian navy is rapidly growing include 'Asia's Navies: Into the Wide Blue Yonder', The Economist, 5 June 2008; Syed Jafar Askari, ‘Growth in Indian Navy Matter of Concern: Noman', The Nation (Lahore), 2 June 2010. For a sceptical view, see 'Report No. 32 - Indigenous Construction of Indian Naval Warships', (New Delhi: Comptroller and Auditor General, 2010).

${ }^{3}$ These figures are drawn from various editions of the International Institute for Strategic Studies' Military Balance between 1991 and 2011.
} 
propulsion systems of individual platforms, the full-load displacement of a ship can be used as a crude proxy for its capability. ${ }^{4}$ The aggregate displacement of the fleet was nearly 30 per cent greater in 2011 (217,426 tons) than 1991 (167,657 tons), despite the lack of growth in the numbers of major platforms, a trend that was most pronounced with respect to frigates and amphibious craft. ${ }^{5}$

Table 2.1 Qualitative measures: displacement and missile complement of major naval platforms

\begin{tabular}{|c|c|c|c|c|c|c|c|}
\hline \multicolumn{4}{|c|}{1991} & \multicolumn{4}{|c|}{2011} \\
\hline & $\#$ & $\begin{array}{l}\text { Displacement } \\
\text { (tons) }\end{array}$ & $\begin{array}{l}\text { Missile } \\
\text { Cells }\end{array}$ & & \# & $\begin{array}{l}\text { Displacement } \\
\text { (tons) }\end{array}$ & $\begin{array}{l}\text { Missile } \\
\text { Cells }\end{array}$ \\
\hline Carriers & & & & Carriers & & & \\
\hline Viraat & 1 & 29,000 & 0 & Viraat & 1 & 29,000 & 0 \\
\hline Vikrant & 1 & 19,800 & 0 & Destroyers & & & \\
\hline Destroyers & & & & Rajput & 5 & 4,974 & $\begin{array}{l}2 \times 30 \\
1 \times 36 \\
2 \times 38\end{array}$ \\
\hline Rajput & 5 & 4,974 & 6 & Delhi & 3 & 6,200 & 18 \\
\hline Frigates & & & & Frigates & & & \\
\hline Godavari & 3 & 3,850 & 4 & Godavari & 3 & 3,850 & 4 \\
\hline Whitby & 2 & 2,560 & 3 & Nilgri & 3 & 2,962 & 0 \\
\hline Nilgri & 6 & 2,962 & 0 & Brahmaputra & 3 & 3,850 & 16 \\
\hline Kamorta & 6 & 1,150 & 4 & Talwar & 3 & 4,035 & 14 \\
\hline Betwa & 1 & 2,520 & 0 & Shivalik & 2 & 5,600 & 14 \\
\hline Submarines & & & & Submarines & & & \\
\hline Kilo & 8 & 2,325 & 0 & Kilo & 10 & 2,325 & $8 \times 6$ \\
\hline$H D W 209$ & 2 & 1,450 & 0 & $H D W 209$ & 4 & 1,450 & 0 \\
\hline Foxtrot & 7 & 2,000 & 0 & Foxtrot & 1 & 2,000 & 0 \\
\hline & & & & Akula II & 1 & 8,100 & 4 \\
\hline Amphibious & & & & Amphibious & & & \\
\hline Kumbhir & 8 & 1,120 & 0 & Kumbhir & 5 & 1,120 & 0 \\
\hline Magar & 1 & 5,665 & 0 & Shardul & 3 & 5,665 & 0 \\
\hline & & & & Magar & 2 & 5,665 & 0 \\
\hline & & & & Jalashwa & 1 & 16,590 & 0 \\
\hline
\end{tabular}

Note: Displacement is full-load displacement.

\footnotetext{
${ }^{4}$ Geoffrey Till, Seapower: A Guide for the Twenty-First Century (London: Frank Cass, 2004), p. 114. This proxy does have limits: as two prominent naval analysts note, the container-ship Emma Maersk has more than half again the displacement of a Nimitz-class aircraft carrier, 'yet no one would mistake such behemoths for warships'. James Holmes and Toshi Yoshihara, 'Understanding Asia-Pacific Sea Power', The Diplomat, 21 October 2010, http: //the-diplomat.com/2010/10/21/understanding-asia-pacific-sea-power.

${ }^{5}$ These figures are drawn from various editions of the International Institute for Strategic Studies' Military Balance between 1991 and 2011.
} 
A second measure of the quality of Indian naval vessels is their number of missile cells carrying anti-ship cruise missiles, land-attack cruise missiles, anti-submarine rockets, or surface-to-air-missiles with a range greater than 8.6 nautical miles. ${ }^{6}$ By this measure, the quality of the fleet has increased significantly. In 1991, the Navy's warships possessed a total 72 missile cells: in 2011, it carried 402 - an increase in striking power, air defence and antisubmarine capability of more than five-and-a-half times, in addition to the improvements in range and accuracy of modern systems.

With the quality of the modern vessels improving moderately as measured by aggregate tonnage and drastically with respect to number of missile cells, it appears that the Navy has sought increasingly capable modern platforms, while being less concerned with the overall size of its fleet. To put Indian developments into perspective, as Table 2.2 indicates, among other major Asian navies, China and Australia are both expanding their fleets and adding more capable platforms (as measured by aggregate tonnage), the South Koreans are expanding their numbers significantly while holding their capability steady, and the Japanese are adding more capable platforms while shrinking the overall size of their fleet.

Table 2.2 Development of major Asian navies 1991-2011

\begin{tabular}{|c|c|c|c|c|c|c|c|c|c|c|c|c|c|c|c|}
\hline & \multicolumn{3}{|c|}{ India } & \multicolumn{3}{|c|}{ Australia } & \multicolumn{3}{|c|}{ China } & \multicolumn{3}{|c|}{ Japan } & \multicolumn{3}{|c|}{ South Korea } \\
\hline & 1991 & 2011 & $\% \Delta$ & 1991 & 2011 & $\% \Delta$ & 1991 & 2011 & $\% \Delta$ & 1991 & 2011 & $\% \Delta$ & 1991 & 2011 & $\% \Delta$ \\
\hline $\begin{array}{l}\text { tonnage } \\
\text { Principal }\end{array}$ & 167,657 & 217,426 & $29.7 \%$ & 56,298 & 88,186 & $56.6 \%$ & 383,109 & 604,142 & $57.7 \%$ & 267,870 & 349,450 & $30.5 \%$ & 90,775 & 141,340 & $55.7 \%$ \\
\hline combatants & 51 & 50 & $-2.0 \%$ & 17 & 21 & $23.5 \%$ & 155 & 171 & $10.3 \%$ & 86 & 72 & $-16.3 \%$ & 24 & 37 & $54.2 \%$ \\
\hline
\end{tabular}

Source: Figures derived from various editions of the IISS Military Balance, 1991-2011.

Is this modernization of the Indian fleet evidence of a desire to emerge as a major maritime power? In nominal terms, the Indian Navy’s budget has gone from Rs 2,090.78 crore ( $\$ 468$ million) in 1991 to Rs $21,467.51$ crore ( $\$ 4.8$ billion) in 2011, a growth of more than 1,000 per

\footnotetext{
${ }^{6}$ Surface-to-air missiles with a range less than $8.6 \mathrm{nmi}(16 \mathrm{~km})$ are not included because they are considered to be strictly self-defence systems. For more discussion, see Robert Work, 'The U.S. Navy: Charting a Course for Tomorrow's Fleet (Washington, D.C.: Center for Strategic and Budgetary Assessments, 2008), p. 10. All ranges in this chapter are given in terms of nautical miles. One $\mathrm{nmi}=1.85 \mathrm{~km}=1.15$ miles.
} 
cent (Figure 2.2). ${ }^{7}$ Moreover, naval spending grew at a slightly faster average annual rate (12.3 per cent) than the [22] overall defence budget (11.5 per cent). Despite this tenfold increase in nominal naval spending, in comparison to the budgetary allocations of the Army and the Air Force (Figure 2.3), the Navy clearly remains the third service. The Navy's relative share of the defence budget increased from a low of 11.5 per cent in 1992-93 [24] to a high of 18.9 per cent in 2006-2007 before regressing to 14.7 per cent by $2010-11$ - a budget share it previously held in 1999-2000. This is far short of the sustained 20 per cent share of defence spending some overly optimistic observers believed that the Navy could achieve, let alone the 30 per cent share recommended by the Standing Committee on Defence in $1998 .^{8}$ It has traditionally been difficult for the Navy to justify allocating scarce defence resources to its capital-intensive fleet given the country's outstanding territorial disputes with both Pakistan and China. As numerous land powers throughout history have found, the resources necessary to become a major maritime power are unlikely to be available as long as India continues to require a large army to protect its territorial integrity. ${ }^{9}$

\section{[Figure 2.2 and Figure 2.3 about here]}

\section{Figure 2.2 Naval expenditure}

\section{Figure 2.3 Total defence expenditure}

\footnotetext{
${ }^{7}$ Budget figures come from Ministry of Defense Defence Annual Reports and Rahul Roy-Chaudhury, India's Maritime Security (New Delhi: Knowledge World, 2000): 146. These figures are not adjusted for inflation.

${ }^{8}$ For suggestions that the Navy could achieve 20 per cent of defence spending, see David Scott, 'India's Drive for a "Blue Water" Navy', Journal of Military and Strategic Studies, 10(2) (Winter 2007-2008), p. 14 and James Holmes, Andrew Winner and Toshi Yoshihara, Indian Naval Strategy in the Twenty-First Century (London: Routledge, 2009), p. 82. For the 30 per cent recommendation, see Standing Committee on Defence, Ministry of Defence - Upgradation and Modernization of Naval Fleet (1998-99), Third Report, Twelfth Lok Sabha, 21 December 1998, p. 8.

${ }^{9}$ Jakub Grygiel, Great Powers and Geopolitical Change (Baltimore: Johns Hopkins University Press, 2006), pp. $169-70$.
} 


\section{Drivers of Indian Naval Development}

What is driving the development of the Indian Navy described in the previous section? The justifications for a robust fleet put forth by naval proponents have remained relatively static despite changing geopolitical circumstances in the six decades since Independence. ${ }^{10}$ The three principal arguments are the need to:

1. Prevent a hostile power from encroaching on the country's expansive coastline and maritime areas of interests.

2. Project power in a manner fitting the country's desired regional or global role.

3. Safeguard the sea lanes which carry India's trade and energy supplies.

To assess the factor most salient in driving naval modernization, each justification will first be compared to the actual risks India faces. Second, the Navy's acquisition patterns over the past two decades will be examined to see if they demonstrate [25] preparation for that mission. Though subject to time lags, platform acquisition can provide a more concrete indication of a navy's priorities since it is a costlier signal of future intentions than the statements of senior policy-makers or proclamations made in service doctrinal publications. ${ }^{11}$ While there is a degree of fungibility among naval platforms, certain vessel types are better suited for some missions than others: a navy configured to deny access to a hostile power, for example, will

\footnotetext{
${ }^{10}$ Compare, for example, Report to the Admiral of the Fleet, 'India and the Royal Indian Navy', 31 August 1949, p. 3, cited in Rahul Roy-Chaudhury, Sea Power and Indian Security (London: Brassey's, 1995), p. 29 with Gary Sojka, 'The Missions of the Indian Navy', Naval War College Review, 36(1) (January-February 1983): 4-5 and Iskander Rehman, 'An Ocean at the Intersection of two Emerging Maritime Narratives', paper presented at 'From Regional Sea to Global Lake: The Indian Ocean in the XXIst Century' (German Marshall Fund: Washington, D.C., 12 November 2010).

${ }^{11}$ On the value of "talk" versus "actions" in signaling intentions, see Charles L. Glaser, 'Political Consequences of Military Strategy: Expanding and Refining the Spiral and Deterrence Models', World Politics, 44(4) (July 1992): 509 and Raymond Garthoff, 'On Estimating and Imputing Intentions', International Security, 2(3) (Winter, 1978): 26.
} 
look different from one primarily designed to influence events on land from the sea. ${ }^{12}$ Thus, by examining the specific mix of vessels in the fleet and the missions they are optimally configured to carry out, it is possible to make a qualified judgement about the Indian Navy's priorities.

Assessment of both vulnerability and platform acquisition suggests concerns about securing the country's sea lanes is the primary factor driving India's naval development. Growth in amphibious lift provides some evidence that power projection is a factor of interest; however, the lack of assets to facilitate operations in hostile littoral environments indicates this capability is focused on 'softer' missions such as non-combatant evacuation and humanitarian response. The least evidence exists to support the idea that concerns about extra-regional powers is the driving factor, as evidenced by the sorry state of India's submarine fleet.

\section{Denying Hostile Maritime Powers}

The desire to defend the country's sphere of influence from hostile powers is one factor potentially driving Indian naval modernization. ${ }^{13}$ India possesses nearly 4,800 miles of coastline and a massive 2.54 million square mile exclusive economic zone that constitutes nearly 10 per cent of the Indian Ocean. American naval analysts have argued that the core of India's maritime strategy is to defend the entire Indian Ocean as the country's 'rightful and exclusive sphere of interest'. ${ }^{14}$ Indeed, 'the arc from [26] the Persian Gulf to the Straits of

\footnotetext{
${ }^{12}$ Stansfield M. Turner, 'Designing a Modern Navy: A Workshop Discussion', in Sea Power and Influence: Old Issues and New Challenges, ed. Jonathan Alford (Farnborough: Institute for Strategic Studies, 1980), p. 67.

${ }^{13}$ Rising states such as India can expect to face challenges from other major powers who would seek to curb its rise for fear that in the future this peer-competitor could pose a threat to their own security. Nicholas Spykman, America's Strategy in World Politics: The United States and the Balance of Power (New York: Harcourt, Brace, 1942), p. 21. For an extended treatment of this argument, see John Mearsheimer, The Tragedy of Great Power Politics (New York: W.W. Norton, 2001).

${ }^{14}$ Eric Margolis, 'India Rules the Waves', US Naval Institute Proceedings, 131(3) (March 2005): 70.
} 
Malacca' is identified by the Indian Navy's 2004 Maritime Doctrine defined as 'a legitimate area of interest .... ${ }^{15}$

Concerns about extra-regional maritime actors in the Indian Ocean precede Independence, with both Indian scholars and politicians linking the country's naval weakness in the sixteenth century to its subsequent conquest by colonial powers. ${ }^{16}$ More recently, the Nixon Administration's gunboat diplomacy during the 1971 Bangladesh War - dispatching the USS Enterprise task force to the Bay of Bengal to signal tacit support for Pakistan - has, according to one Indian scholar, 'seeped into India's cultural memory - even among those who know nothing of the sea' ${ }^{17}$ Concern that extra-regional powers would seek to establish a lasting presence in the Indian Ocean would appear to be particularly acute today since the Navy's 2004 maritime doctrine predicts, all 'major powers of this century will seek a toehold in the [Indian Ocean Region]' ${ }^{18}$ In particular, the Navy's maritime strategy gives explicit attention to the Chinese navy's actions in the Indian Ocean. ${ }^{19}$ Beijing's efforts to establish a network of ports and partnerships with countries in the littoral region - including several nations that have traditionally been hostile to India - have alarmed many in India's strategic community. ${ }^{20}$ As a result, some scholars have suggested that 'it is India's fears and

\footnotetext{
${ }^{15}$ Integrated Headquarters, Ministry of Defence (Navy), INBR-8, Indian Maritime Doctrine, 2004, p. 56.

${ }^{16}$ K.M. Panikkar, India and the Indian Ocean: An Essay on the Influence of Sea Power on Indian

History (New York: Macmillan, 1945): 7; Indira Gandhi, Opening Address, Commonwealth Heads of Government Meeting, Asia-Pacific Region, New Delhi, 4 September 1980.

${ }^{17}$ The characterization of the event as gunboat diplomacy comes from Stephen Cohen and Sunil Dasgupta, Arming without Aiming (Washington, D.C.: Brookings, 2010), p. 75. The quote comes from James Holmes, Andrew Winner and Toshi Yoshihara, Indian Naval Strategy in the Twenty-First Century (London: Routledge, 2009), p. 39.

${ }^{18}$ Integrated Headquarters, Ministry of Defence (Navy), INBR-8, Indian Maritime Doctrine, 2004, p. 52.

${ }^{19}$ Integrated Headquarters, Ministry of Defence (Navy), Freedom to Use the Seas: India's Maritime Military Strategy, 2007, p. 41.

${ }^{20}$ B. Raman, 'Hambantota \& Gwadar: An Update', South Asia Analysis Group, 12 June 2009; Mukul Devichand, 'Is Chittagong One of China's “String of Pearls?”, BBC News, 17 May 2010; Nitin Gokhale, 'How India is Undoing China's String of Pearls', Rediff.com, 7 October 2010.
} 
perceptions of the growing naval prowess of China in the Indian Ocean that is driving Indian naval posture'. ${ }^{21}[27]$

Do extra-regional maritime powers pose a sufficient threat to drive India's naval modernization programme? While India's Independence may have historically been linked to sea control, it hyperbole to advance that argument today. A hostile maritime power seeking to invade India from the sea would have to withstand the power of the Indian Air Force in their approach to the shore. Any forces surviving this initial bombardment would then find that India's coastline has few landing zones adjacent to strategic objectives that would make an amphibious assault worthwhile. ${ }^{22}$ Although, as the 2008 attacks on Mumbai demonstrated, the possibility of a terrorist group infiltrating India by sea is real, the appropriate responses to this threat are inshore patrol craft and the creation of specialized coast guard units to protect India's ports and coastline, not blue-water warships. Although a cause for concern during the Cold War, the burgeoning Indo-American strategic partnership means that the U.S. Navy is now a welcome sight in the Indian Ocean. With respect to China, over the last 15 years, senior Chinese military personnel have suggested that they don't recognize the Indian Ocean as India's exclusive domain. ${ }^{23}$ However, with 75 per cent of its surface vessels considered obsolete and only possessing a limited power projection capability, the Chinese navy is configured to prevent US intervention in a crisis involving Taiwan, not projecting power

\footnotetext{
${ }^{21}$ Harsh V. Pant, 'India in the Indian Ocean: Growing Mismatch Between Ambitions and Capabilities', Pacific Affairs, 82(2) (Summer 2009): 290. For a similar view, see Scott, 'India's Drive for a "Blue Water” Navy', p. 1. Long-time scholar of Indian maritime issues Rahul Roy-Chaudhury calls China's presence in the Indian Ocean the Indian Navy's 'key strategic challenge.' Rahul Roy-Chaudhury, 'Maritime Ambitions and Maritime Security', presentation delivered to the 5th Berlin Conference on Asian Security, 30 September 2010, www.swpberlin.org/fileadmin/contents/products/projekt_papiere/Roy-Chaudhury_BCAS2010_web_ks.pdf.

${ }^{22}$ Michael O'Hanlon reports that generally, 'only about 20 percent of the world's coastlines are considered suitable for amphibious assault.' Michael E. O’Hanlon, The Science of War (Princeton: Princeton University Press, 2009), p. 91.

${ }^{23}$ Quoted in Geoffrey Barker, 'Jostling Giants', Inside Story, 4 February 2011, http: //inside.org.au/jostling-giants.
} 
abroad. $^{24}$ There would have to be a significantly favourable shift in the naval balance in East Asia before Beijing could seriously entertain a sustained presence in the Indian Ocean.

Turning to the configuration of the Indian fleet, the development of a robust sea-denial capability would provide evidence that concern about extra-regional actors was driving naval modernization. Since the early 1900s, 'the weapon of choice' for sea-denial missions has been the submarine. ${ }^{25}$ This is particularly true in the Indian Ocean where the peculiar underwater topography, salinity and thermoclines all hinder the ability of sonar to detect submarines and other underwater objects. Therefore, a significant modernization of India's submarine fleet would provide the most apparent evidence of a focus on sea-denial.

In 1991 the Indian Navy possessed seven obsolete Russian Foxtrot (INS: Vela/Kalvari) class diesel-electric submarines, two German HDW 209s [28] (INS: Shishumar), and eight modern Russian-built Kilo (INS: Sindhughosh) class boats, the last of which was one of the quietest diesel submarines in the world. In the ensuing two decades, the submarine fleet has undergone a steady decline. The fleet did add a pair each of HDW 209s and Kilos while seven of the older Kilos were upgraded to the Type 636 standard which equipped them with modern fire control systems, advanced torpedoes and anti-ship cruise missiles. Meanwhile, all but one of the Foxtrots were removed from service and the majority of the remaining submarines approached the end of their operational life. By October 2009, the Comptroller and Auditor General estimated that the submarine fleet's operational readiness rate had fallen below 50 per cent, a shortcoming exacerbated by the fact that the Navy only possessed $2 / 3$ of the number of submarines envisioned by planners in the $1980 \mathrm{~s}^{26}$

\footnotetext{
24 'Military and Security Developments Involving the People's Republic of China' (Washington, D.C.: US Department of Defense, 2010), pp. i, 45 and James Holmes and Toshi Yoshihara, 'China's Naval Ambitions in the Indian Ocean', Journal of Strategic Studies, 31(3) (2008): 368.

${ }^{25}$ Owen Cote, 'The Third Battle: Innovation in the U.S. Navy's Silent Cold War Struggle with Soviet Submarines', Newport Paper, No. 16, 2003, p. 1; Eric Grove, Sea Power (London: Routledge, 1990), p. 134.

${ }^{26}$ 'Report No. 16 - for period ended 2008-09 Union Government (Defence Services) - Air Force and Navy', (New Delhi: Comptroller and Auditor General, 2010), p. 30.
} 
The lethargic pace with which the MoD has pursued new submarines demonstrates the relative lack of interest in the submarine fleet. A contract for six French-designed Scorpene subs was only signed in 2005 , at a time when five of the seven Foxtrots had already been withdrawn from service. The first of these Scorpenes was not even scheduled to be delivered until 2012, which would be a dozen years since the most recent submarine entered the fleet. With the inevitable delays in procurement programmes, however, by the time the first Scorpene is actually inducted in the middle of the decade, it has been estimated that India will only have between five and nine operational submarines left. Even with the most optimistic assumptions, this will fall significantly short of the minimum of 18 conventional submarines believed necessary to effectively deter hostile maritime powers. ${ }^{27}$

Despite the obvious fact that 'India is in dire need of modern submarines', there has been no attempt to fill the gap through a short-term lease or other rapid acquisition programme. ${ }^{28}$ Instead, a tender for six additional submarines was issued in 2010, which will not even be signed before $2012-13 .^{29}$ The priority given to developing the capacity of government shipyards has meant that the Navy's request to speed delivery of these six additional submarines by building them in private shipyards - rather than the already overburdened state-owned Mazagon Docks—-was overruled. ${ }^{30}$

Nothing about the state of India's submarine fleet suggests developing an anti-access capability to deter extra-regional powers is a prime concern. Nor would [29] the submarine capability that the Navy is projected to possess in the 2015-20 timeframe be sufficient to prevent an extra-regional power from establishing a presence in the region. Thus we cannot give significant weight to the idea that Indian naval modernization is chiefly driven by

\footnotetext{
27 'Navy to Train for Scorpene Subs', Times of India, 18 May 2011, http: //articles.timesofindia.indiatimes.com/2011-05-18/india/29555290_1_scorpene-project-mdl-project-75.

${ }^{28}$ Eric Wertheim, ‘World Navies in Review', U.S. Naval Institute Proceedings, 136(3) (March 2010): 45.

${ }^{29}$ Sandeep Unnithan, 'France to Offer Bigger Scorpenes for \$5 Billion Indian Submarine Order’, India Today, 6

December 2010.

30 'Biggest Military Deal: Six Subs for Rs 50,000 crore', Times of India, 11 July 2010.
} 
perceived threats to the homeland posed by hostile maritime powers. Fortunately, India has friendly relations with the most powerful extra-regional navy in the Indian Ocean, the United States, while the potential naval challenge from China appears many years off.

\section{Power Projection for Great Power Status}

The desire to gain a maritime power projection capability as a marker of great power status is a second factor that has been posited to drive Indian naval modernization. With the ability to project military power abroad having been identified as a core characteristic of a great power, a rising state such as India could have ample reason to want to enhance its military power projection capabilities. ${ }^{31}$ In this vein, scholars such as Ashley Tellis believe that 'India's rise to power will remain incomplete until it acquires, and develops, the capacity to effectively utilize the full panoply of military power' ${ }^{32}$

\footnotetext{
${ }^{31}$ On the link between military power projection and great power status, see Hedley Bull, The Anarchical Society (New York: Columbia University Press, 1995), p. 195; Mearsheimer, The Tragedy of Great Power Politics, p. 81; Christopher Layne, 'China's Role in American Grand Strategy: Partner, Regional Power, or Great Power Rival?', in The Asia-Pacific: A Region in Transition, ed. Jim Rolfe (Honolulu, HI: Asia-Pacific Center for Security Studies, 2004), p. 66; David J. Karl, 'India's Emergence as a Great Power: Implications for U.S. Policy in Asia', speech presented at MIT’s Security Studies Program Seminar, 21 October 2009; Brahma Chellaney, 'India’s Missing Hard Power', Mint [New Delhi], 21 April 2010. While conventional wisdom suggests India's traditional foreign policy orientation all but precludes projection of military power beyond its territory, this ignores the fact that India has not hesitated to 'sort out' its neighbours when New Delhi felt that its interests were threatened. Moreover, it fails to appreciate that military power projection has both hard and soft power aspects. Thus, when called upon to do so by national interest, the Indian military has undertaken armed intervention in the Maldives; compulsion operations in Sri Lanka; and showed the flag in the South China Sea as well as non-combatant evacuation operations in Lebanon and humanitarian relief missions in Southeast Asia. For an extended discussion, see Walter C. Ladwig III, 'India and Military Power Projection: Will the Land of Gandhi Become a Conventional Great Power?' Asian Survey, 50(6) (November/December 2010): 1162-83.

${ }^{32}$ Quoted in Amy Zalman, review of Stephen Cohen and Sunil Dasgupta, Arming Without Aiming, in South Asian Idea, http: //southasianidea.com/book-reviews.
} 
Observing that, since 1500 , the leading maritime powers have been the leading powers in the world, George Modelski and William Thompson argue that maritime power - vice land-power or airpower - is what determines great power [30] status. ${ }^{33}$ From an early age the Indian Navy recognized the link between maritime power and international status: its initial 1947 expansion plan identified naval development as a means of achieving 'a position of preeminence and leadership among the nations of South-East Asia'. ${ }^{34}$ In this vein, some contemporary analysts believe 'the general posture of the [Indian Navy] is power projection, an aspiration pushed hard by the Navy itself, but endorsed in principal by governments of all political persuasion, and enthusiastically supported by the population at large' ${ }^{35}$ The Navy's 2007 maritime strategy would appear to sanction this view as it repeatedly mentions the need to 'project power' to support the country's foreign policy objectives and achieve its national aims. $^{36}$

Since humans live on land, not on the sea, however, the projection of maritime power must ultimately have an impact onshore. As a result, it has been suggested India's naval modernization is driven by a particular desire to boost its ability to decisively influence military operations on land. ${ }^{37}$ Towards that end, in 2008, then-Chief of Naval Staff Admiral Sureesh Mehta declared that his goal for 2020 was a navy that would be capable of influencing the outcome of land battles and performing a constabulary role in the Indian Ocean region'. ${ }^{38}$

\footnotetext{
${ }^{33}$ Since the 1500 s the leading maritime powers have been the world's leading powers. George Modelski and William R. Thompson, Seapower in Global Politics, 1494-1993 (London: The Macmillan Press, 1988), p. 13. For a contrary view, see Mearsheimer, The Tragedy of Great Power Politics, pp. 83-137.

${ }^{34}$ Quoted in Roy-Chaudhury, Sea Power and Indian Security, p. 27.

35 'India', Jane's World Navies, 26 June 2009.

${ }^{36}$ Integrated Headquarters, Ministry of Defence (Navy), Freedom to Use the Seas, pp. iv, 11.

${ }^{37}$ See, for example, Arunkumar Bhatt, 'Focus on Navy's Influence on Land Operations', The Hindu (Chennai, India), 7 May 2006 and Pant, 'India in the Indian Ocean,' p. 296.

${ }^{38}$ Quoted in Bedi, 'Getting in Step'.
} 
Control of the sea, which is the ability to operate 'with a high degree of freedom in a sea or ocean area ... for a limited period of time', is a fundamental prerequisite for both power projection and the protection of sea lanes (the latter of which is discussed in the subsequent section. ) $^{39}$ However, sea control alone is not sufficient for the more demanding mission of maritime power projection onshore, which can take two general forms: amphibious assault by ground troops and strikes by carrier aircraft and cruise missiles. Although the precision and reach of naval aircraft and cruise missiles makes them potent tools, both scholars of naval strategy such as Geoffrey Till and international relations theorists like John Mearsheimer contend that amphibious operations remain 'the main subset of maritime power projection' ${ }^{40}$ In contrast, bombardment with missions or carrier aircraft are derided as 'pinprick [31] warfare' that 'has little effect on the target state'. ${ }^{41}$ Thus, a concrete indication that power projection was driving India's naval development would be a significant expansion in amphibious capability, namely the acquisition of platforms that can transport a significant number of troops overseas. ${ }^{42}$ A secondary indication would be the cultivation of the ability to carry out air and missile strikes on shore.

Twenty years ago the Navy could transport 1,800 men and 55 tanks with a single Magar class landing ship tank (LST) and eight Kumbhir class (Polish: Polnocy variant) medium landing ships (LSM). In 2011, the Navy's amphibious complement has the notional ability to move a brigade-sized force of 4,300 men, 100 tanks and several dozen armoured vehicles. In addition to the 19,000-ton landing platform dock INS Jalashwa (US: Austin class), which is the second-largest ship in the fleet and can transport a thousand soldiers by itself, the Navy possesses five Magar and Shardul class LSTs and five remaining Kumbhir LSMs.

\footnotetext{
${ }^{39}$ Milan N. Vego, Naval Strategy and Operations in Narrow Seas (London: Frank Cass, 2003), p. 111.

${ }^{40}$ Till, Seapower, p. 199; Mearsheimer, The Tragedy of Great Power Politics, pp. 88-9.

${ }^{41}$ Mearsheimer, The Tragedy of Great Power Politics, pp. 88-9.

${ }^{42}$ J. Paul Reason, Sailing New Seas (Newport: Naval War College Press, 1998), p. 18.
} 
The Navy has employed this expanded capability in a number of high-profile humanitarian response and non-combatant evacuation operations that have attracted worldwide attention. Following the 2004 Asian tsunami, the Indian Navy mobilized 32 ships and over 20,000 naval personnel to evacuate casualties, as well as provide emergency sources of power and water to the peoples of Sri Lanka, the Maldives, Indonesia, Thailand and Malaysia. Two years later, during Operation Sukoon, the Navy evacuated 2,280 Indian, Sri Lankan and Nepalese civilians from Lebanon ahead of the 2006 Israeli-Hizbollah War. These operations have burnished India's credentials as a net provider of security and enhanced its regional reputation in line with the predictions of the analysts cited above. Consequently, in December 2010, the Cabinet Committee on Security approved the Navy's plan to acquire four additional LPDs of a similar size as the Jalashwa; however, given the chequered history of Indian naval construction, it could be the mid 2020s before they actually come into service. ${ }^{43}$

Amphibious ships are sufficient for softer power projection missions such as responding to humanitarian crises and evacuating non-combatants from conflict zones. ${ }^{44}$ However, to operate in hostile littoral waters, these platforms would need support from vessels with robust anti-submarine and anti-air capabilities. There should be evidence of a focused effort to acquire these facilitating capabilities if the projection of hard military power were in fact a key goal of the Navy. Although the Navy possesses modern sonar of an international standard, its principal anti-submarine warfare (ASW) surface vessels are far too large to effectively hunt [32] submarines in littoral waters. ${ }^{45}$ Similarly, air defence is

\footnotetext{
${ }^{43}$ Twenty years elapsed between the start of design for the Delhi-class destroyers and the commissioning of the first platform. The interval was 13 years for the Shivalik-class frigate.

${ }^{44}$ On the distinction between hard and soft military power projection, see Ladwig, 'India and Military Power Projection', pp. 1166-69.

${ }^{45}$ For a discussion of ideal platforms for littoral ASW, see Milan Vego, 'Patrolling the Deep', Armed Forces Journal, September 2008. The Navy does have plans to acquire ASW corvettes of the Kamorta-class, which would be appreciated for this mission; however the first of these will not be commissioned until mid 2012.
} 
significantly more challenging close to shore than in the open ocean. ${ }^{46}$ Possessing a moderate area air-defence capability, India's surface fleet would have difficulty screening a task force from hostile ground-based aircraft. Not only are ground-based aircraft able to marshal greater numbers close to shore than they could at sea, the clutter of land creates backscatter which affects radar returns, impeding detection rates of hostile aircraft by air-defence radars. One of India's aircraft carriers could theoretically take up this mission; however, only 11 of the Navy's 30 Mk. 51 Sea Harrier fighters remain in service. Moreover, as of April 2012, the naval version of the domestically designed Tejas lightweight fighter, which is supposed to replace the Harriers for air-defence missions, has only just made its initial test flight.

With respect to the second aspect of maritime power projection, the Navy has not demonstrated a concerted effort to acquire a robust ability to undertake strikes against groundbased targets with either naval aircraft or cruise missiles. Given the common association of aircraft carriers with power projection, the steady deterioration of India's aircraft carrier capability since 1991 is telling. Having possessed two light fleet carriers in 1991, the INS Vikrant (UK: Majestic) was decommissioned in 1997, and the 58-year-old Viraat (UK: Centaur), is on its last legs having already undergone four mid-service refits to extend its lifespan. The Navy could find itself without a carrier for several years should induction of the 44,500-ton, Russian-built INS Vikramaditya (RU: Kiev) - which is expected to join the fleet at the end of 2012 - or the domestically built 40,000-ton 'new' Vikrant (Project 71) currently under construction in Cochin - be delayed beyond the middle of the decade.

The pace and means of India's aircraft carrier acquisition does not demonstrate a rush to expand its carrier capability. Having possessed only a single operational carrier since 1997, the deal to purchase the Vikramaditya was not signed until seven years after the decommissioning of the original Vikrant. Moreover, the Vikramaditya was not even scheduled to be delivered until 2008, the time that the Viraat itself was supposed to be withdrawn from service. The decision to opt for indigenous construction of the both the new

\footnotetext{
${ }^{46}$ O'Hanlon, The Science of War, p. 87.
} 
Vikrant and a third carrier - when India's domestic shipyards have never before built ships of that size - suggests India places a higher priority on enhancing domestic shipbuilding capacity than immediately acquiring naval airpower projection capability.

The limited strike capability of the actual aircraft complement of India's forthcoming carriers also suggests that hard power projection ashore is not a priority. Each new carrier will carry only $12-16$ fighters, meaning that even operating in tandem, two Indian carriers would produce less striking power than the French carrier Charles de Gaulle and nowhere near that of a single US super [33] carrier. American naval analysts have judged that, 'even armed with precision-guided munitions, a contingent of this size could sustain only a modest land bombardment, and only for a modest time'. ${ }^{47}$ If naval strike operations were a serious focus for the Navy, a robust airborne early warning (AEW) capability would be crucial for protecting both the carrier and its aircraft when operating close to a hostile shore. However, Indian naval officials have recently suggested that the acquisition of fixed-wing AEW assets for the new carriers is not a priority. ${ }^{48}$

Strikes with cruise missiles face a similar range constraint as carrier aircraft. The 156 nmi range supersonic BrahMos cruise missile is the Indian Navy's premier surface-strike weapon. Although the BrahMos is three times faster than the US Tomahawk cruise missile, with a top speed of Mach 2.5, it has only one-tenth the range. The same shortcoming also affects the Russian-designed 3M-54 Klub cruise missile (148 $\mathrm{nmi}$ range) in service with the Indian Navy. Even against a state with a modest anti-access capability, the relatively short range of these missiles would render surface-launched cruise missile strikes a risky proposition. A subsonic cruise missile with a range of $540 \mathrm{nmi}$, is currently being developed by India's Defence Research and Development Organization; however, test flights of the

\footnotetext{
${ }^{47}$ Holmes et al., Indian Naval Strategy in the Twenty-First Century, pp. 86-7.

48 'Indian Navy Pursues Fixed-Wing Carrier AEW', Aviation Week, 16 June 2010.
} 
missile have been repeatedly delayed and are not expected to occur until late 2012 at the earliest. $^{49}$

There is mixed evidence to support the idea that power projection is India's primary naval concern. Despite doubling its amphibious lift capability, the Navy has not acquired new amphibious platforms at a particularly rapid pace. Between 2007 and 2009 the Jalashwa and three Shardul class LSTs were acquired; however, prior to that, the only acquisition was a single Magar LST in 1997. Consequently, a number of India's amphibious ships - including the second-hand Jalashwa which was originally launched in 1968 - are quite old. Moreover, the land-attack capability India is acquiring is poorly suited to carry out strikes against states with even a rudimentary anti-access capability. This suggests that rather than the projection of hard maritime power abroad a focus on the 'softer' aspects of power projection, such as the disaster relief and non-combatant evacuation missions that have won the Navy international praise in the past, are a focus of naval development.

\section{Securing Shipping}

The imperatives of protecting India's trade and energy lifelines is a third factor posited to motivate naval development. As ships transit the open ocean, which Mahan described as 'a great highway ... over which men may pass in all directions', they follow 'some well-worn paths' known as trade routes in a previous age and [34] sea lines of communication (SLOCs) today. ${ }^{50}$ The sea remains the primary medium for transporting goods worldwide, which raises concerns for trading nations that vital sea lanes could be disturbed by piracy, war or the actions of a hostile power.

Indian naval enthusiasts have long argued that 'the essential dependence of [India's] trade on maritime traffic ...' means '... the economic life of India will be completely at the

\footnotetext{
${ }^{49}$ Douglas Barrie and Neelam Mathews, 'SU-30MKI to Get Indian Nirbhay Cruise Missile', Aviation Week, 10 May 2010.

${ }^{50}$ Alfred T. Mahan, The Influence of Sea Power upon History (New York: Cosimo Classics, 2007), p. 25.
} 
mercy of the power which controls the seas' ${ }^{51}$ In this vein, the Navy's early leaders believed their primary purpose was 'the protection of India's shipping and lines of communication'. ${ }^{52}$

Today roughly 90 per cent of India's trade by volume and 77 per cent by value is seaborne, and of the country's top 10 trading partners only one shares a border with India. ${ }^{53}$ Since the economic reforms initiated in 1991, the importance of international trade to the Indian economy has increased appreciably. India's import and export of merchandise, in current dollars, was 14 times larger in 2010 than it was in 1991, while its trade-to-GDP ratio has climbed from 17.1 per cent in 1991 to 43.6 per cent in $2009 .{ }^{54}$ Physically situated adjacent to the primary maritime trade routes crossing the Indian Ocean, India's Maritime Strategy notes that 'being the major maritime power in the [Indian Ocean region], a large part of the responsibility for ensuring the safety of international shipping lanes devolves upon the Indian Navy'. ${ }^{55}$

The significance of the goods trade for the Indian economy is trumped by the need to guarantee adequate energy resources for sustained economic growth. India's oil consumption is expected to double present day consumption by 2025 and by some estimates India is expected to become the world's third largest energy consumer by $2030 .{ }^{56}$ As the Navy's Maritime Strategy recognizes, 'India's entire development process depends on the availability

\footnotetext{
${ }^{51}$ Panikkar, India and the Indian Ocean, p. 14.

${ }^{52}$ Quoted in Roy-Chaudhury, Sea Power and Indian Security, p. 27-9.

${ }^{53}$ Rahul Bedi, 'Getting in Step: India Country Briefing', Jane’s Defense Weekly, 6 February 2008. India's top 10 trade partners are China, the United States, the United Arab Emirates, Saudi Arabia, Germany, Singapore, the United Kingdom, Hong Kong, Belgium and the Netherlands.

${ }^{54}$ World Bank, 'India', World Development Indicators, http: //data.worldbank.org/country/india; World Trade Organization, ‘Time Series on International Trade', http: //stat.wto.org.

${ }^{55}$ Integrated Headquarters, Ministry of Defence (Navy), Freedom to Use the Seas, pp. 54, 96. See also Integrated Headquarters, Ministry of Defence (Navy), INBR-8, Indian Maritime Doctrine, 2004, pp. 63-4.

${ }^{56}$ Michael Kugelman, 'Integrating Energy Concerns into India’s National Security Strategy', Journal of Energy Security (December 2011).
} 
of energy resources, ${ }^{57}$ Imports [35] are expected to account for 80 per cent of the India's energy needs by the first quarter of the century ${ }^{58}$ With Saudi Arabia (18 per cent), Iran (16 per cent), Kuwait (10 per cent) and Iraq (9 per cent) emerging as India's principal sources of foreign oil, nearly 65 per cent of its energy comes from the Persian Gulf. ${ }^{59}$ The Navy's Maritime Strategy explicitly notes that protecting the country's oil and gas supply lines 'will remain a primary responsibility of the Indian Navy'. ${ }^{60}$

The ability to exert sea control along the entire distance of India's primary sea lanes is a prerequisite for securing the country's trade and energy flows. ${ }^{61}$ This means not only in the northern Indian Ocean, but as far as the Strait of Hormuz to the west and the Straits of Malacca to the east. The capacity to exercise control over the surface, air and subsurface of a given area is a prerequisite for protecting sea lanes in the open ocean against a hostile naval power. A fleet optimized to guard SLOCs will have a robust anti-surface warfare capability including advanced maritime surveillance and precision-strike capability; open ocean ASW capability; and area air defence provided by modern destroyers or aircraft carriers. ${ }^{62}$

At the end of the Cold War, the Indian Navy possessed two light fleet carriers, five Rajput class (RU: Kashin II variant) guided-missile destroyers and a dozen frigates of various classes. The destroyers were equipped for anti-aircraft roles, with SA-N-1 surface-to-air

\footnotetext{
${ }^{57}$ Integrated Headquarters, Ministry of Defence (Navy), Freedom to Use the Seas, p. 46. For a similar view from the MEA, see Annual Report 2007-2008 (Delhi: Ministry of External Affairs, 2008): i.

${ }^{58}$ Carin Zissis, 'India’s Energy Crunch', Backgrounder (Washington, D.C.: Council on Foreign Relations, 23

October 2007) www.cfr.org/publication/12200/.

${ }^{59}$ Energy Information Administration Country Analysis Brief, 'India', (Washington, D.C.: Department of Energy, August 2010), www.eia.doe.gov/EMEU/cabs/India/pdf.pdf.

${ }^{60}$ Integrated Headquarters, Ministry of Defence (Navy), Freedom to Use the Seas, pp. 46, 49.

${ }^{61}$ Milan N. Vego, Naval Strategy and Operations in Narrow Seas (London: Frank Cass, 2003), p. 111.

${ }^{62}$ For a discussion of the requirements of sea control, see Barry Posen, 'Command of the Commons: The Military Foundations of U.S. Hegemony', International Security, 28(1) (Summer 2003): 11; and Andrew S. Erickson and Lyle J. Goldstein, 'Gunboats for China's New "Grand Canals”? Probing the Intersection of Beijing's Naval and Energy Security Policies', Naval War College Review, 62(2) (Spring 2009): 62.
} 
missiles providing local area air defence with a range of 19 nmi. The Navy's destroyers and frigates all possessed modest anti-submarine warfare capabilities in the form [36] of basic hull-mounted sonar systems torpedo tubes, anti-submarine rocket launchers, and a total of 11 embarked ASW helicopters. The principal anti-surface weapon aboard these ships was the 37 nmi ranged Russian SS-N-2C ‘Styx’ missile.

Over the past two decades the quality of the surface fleet has improved in key areas. The three Delhi class guided-missile destroyers, commissioned in the late 1990s, are the largest indigenously designed and built vessels in the Indian Navy with a displacement 25 per cent greater than the Rajput series. During the same period, the Navy has added three new classes of frigate, the Brahmaputra, Talwar (RU: Krivak III) and Shivalik - the last of which are nearly the size of the Delhi class destroyers. Anti-surface capability on these new platforms come in the form of the $70 \mathrm{nmi}$ SS-N-25 'Switchblade' anti-ship missile - which is equivalent to the US Navy's Harpoon Block 1C - as well as the supersonic BrahMos. In the ASW realm, the deployment of modern towed array sonar provides an ASW capability that is significantly better than the old hull-mounted panoramic sonar. Moreover, the surface fleet's combined complement of embarked ASW helicopters has tripled over the past two decades as virtually every destroyer and frigate now carries one or more Sea King, Druv or Helix ASW helicopter. The picture is not quite as bright in the air-defence realm where the Delhi class's SA-N-7 Gadfly - one of the most effective intermediate-range ship-to-air missiles in use today - provides local area air defence for the fleet to a range of $17 \mathrm{nmi}$. The Talwar frigates are equipped with a slightly more modern surface-to-air missiles than the Delhi destroyers, which with a range of $24 \mathrm{nmi}$ provide a moderate level of fleet air-defence capability that is a qualitative step up from the Navy's capability in 1991. However, these systems contrast unfavourably with the $80 \mathrm{nmi}$ ranged SA-N-20 SAMs on the Chinese Luzhou class destroyer or the 100 nmi extended-range standard missile employed by the United States Navy.

In light of the twin observations that carrier capabilities experience increasing marginal returns with respect to size and that 50,000 tons is the cross-over point where carrier-based aviation is cheaper than land-based counterparts, India's decision to opt for medium-sized 
(40,000 ton) carriers is suggestive. ${ }^{63}$ These ships' expected complement of Mig-29K and the HAL Tejas fighters can provide area air defence for a naval task force, but, as previously noted, would not have significant strike capability against land-based targets. Progression from light fleet carriers to medium-sized ones, rather than jumping directly to a $60,000+$ ton platform as the Chinese are attempting to do, is a linear step in line with India's growing domestic technology base; however, it is also suggestive of the Navy's priorities that these medium-sized carriers are more suited for sea-lane protection that power projection.

In contrast to the other two factors, there is the most evidence to support the idea that sea-lane security is driving India's maritime development. In comparison to the 'threats' posed by extra-regional navies or the need to project naval power to signal great power status, the fact that the Navy's surface fleet has received the bulk of the attention vis-à-vis the submarine and amphibious fleets over the past two decades suggests that the vulnerability of India's overseas trade and energy supplies are the most salient needs for India's politicalmilitary leadership to address. The fleet's complement of destroyers and frigates has seen a host of new designs, some of which exhibit significant upgrade in capability from their predecessors. Anti-surface warfare capability demonstrates the most robust improvement; however, [37] the advance in the fleet's area air defence is also an important improvement, albeit far from the best in the world.

\section{Bureaucratic Politics?}

Given this chapter's focus on external factors driving naval procurement decisions, before concluding it is reasonable to ask whether this behaviour is better explained by bureaucratic

\footnotetext{
${ }^{63}$ For example, a 50,000-ton carrier can embark almost twice as many aircraft as a 40,000-ton carrier. 'New Carriers', The Naval Review, L(4) (October 1962): 380; for the importance of the 50,000-ton threshold, see Ashley Tellis, 'Aircraft Carriers and the Indian Navy: Assessing the Present, Discerning the Future', Journal of Strategic Studies, 10(2) (1987): 143-4.
} 
politics either within the Navy or the armed forces more broadly? ${ }^{64}$ A comprehensive answer to this question is beyond the scope of this chapter, but it is possible briefly to explore these two issues. Since each of the services develops their procurement and acquisition plans in isolation, the natural starting point would be the intra-service politics of the Indian Navy. It has been suggested, for example, that in the US Navy dominant communities such as carrier aviation and attack submarines garner a disproportionate share of appointments of officers at the highest levels and resources for their own projects at the expense of lower prestige communities. ${ }^{65}$ Thus, overall naval plans may be a reflection of the desires of these powerful sub-components rather than the rational preferences of the organization as a whole. In the Indian Navy, the dominant community is the executive branch. Unlike engineering and electrical officers, only officers from the executive branch can exercise command of ships, submarines and aircraft, and therefore have any chance of achieving the highest ranks in the Navy. One result of this configuration is that the individual identities of officers as aviators or submariners do not arouse the same parochial feelings about their platform community that they might in other navies. Moreover, with the leadership of the Navy at the highest levels chosen solely on the basis of seniority (age), it would be very difficult for a particular community to ensure its prolonged dominance of the organization as a whole. Indeed, during the 20 -year period covered by this study, the Indian Navy has been variously led by aviators, communications specialists, amphibious warfare officers and submariners, among others. Thus, there is reason to believe that intra-service politics has less of an impact in shaping service priorities than might be the case in other navies.

\footnotetext{
${ }^{64}$ The classic treatment of bureaucratic politics in policy making is Morton Halperin, Priscilla Clapp and Arnold Kanter, Bureaucratic Politics and Foreign Policy (Washington, D.C.: Brookings Institution Press, 2007).

${ }^{65}$ Carl Builder, The Masks of War: American Military Styles in Strategy and Analysis (Baltimore: Johns Hopkins University Press, 1989), p. 25. For a contrary view, see Edward Rhodes, 'Do Bureaucratic Politics Matter? Some Disconfirming Findings from the Case of the U.S. Navy', World Politics, 47(1) (1994): 1-41.
} 
With respect to the impact of inter-service politics on acquisition plans, the situation is somewhat similar. ${ }^{66}$ There is no doubt that inter-service politics exist [38] in the Indian military, as in all militaries. ${ }^{67}$ However, it is not clear that it plays a major role in shaping acquisition plans; indeed, a major critique of Indian defence acquisitions is that each of the services develops its plans in isolation. ${ }^{68}$ Rather than pitting the three services against each other, an environment of expanding defence budgets appears to have led the heads of the three services to enter into a tacit agreement not to stand in the way of each other's priorities when formulating an integrated acquisition plan for the armed forces. According to a former Chairman of the Chiefs of Staff Committee, Admiral Arun Prakash, 'commenting on the acquisition plan of the other services was considered taboo and, as a result, the integrated plan was a bundle of all of our plans' ${ }^{69}$ As a result, it falls to the civil servants of the Ministry of Defence to prioritize the services' procurement plans and undertake major procurement decisions. ${ }^{70}$ This system has not resulted in effective integration of service strategies; however, it is not clear that it has resulted in inter-service competition to the point where it plays a key role in driving naval acquisition decisions. Thus, while intra- and inter-service politics undoubtedly affects the Navy's acquisition decisions on some level, it is more fruitful to explore the external pressures driving decision-making about the fleet than the internal ones.

\footnotetext{
${ }^{66}$ For the general suggestions that inter-service politics affect military policymaking, see George C. Wilson, This War Really Matters (Washington, D.C.: CQ Press, 2000), pp. 184-5.

${ }^{67}$ Anit Mukherjee, 'Facing Future Challenges: Defense Reform in India', The RUSI Journal, 156(5)

(October/November 2011): 32.

${ }^{68}$ Cohen and Dasgupta, Arming without Aiming, pp. 150-54.

${ }^{69}$ Quoted in Anit Mukherjee, Failing to Deliver: Post-Crises Defence Reforms in India, 1998-2011 (New Delhi: Institute for Defence Studies and Analysis, March 2011), p. 40.

${ }^{70}$ Mukherjee, 'Facing Future Challenges', p. 32.
} 


\section{Conclusion}

Modernizing, but not growing, is the best way to describe developments in the Indian Navy since 1991. Although, the pace of this modernization does not suggest significant pressure to quickly improve naval capabilities, the fleet of 2011 is significantly more capable it was in 1991. A review of both the risks faced by India and the acquisition patterns of the Navy suggests modernization is being driven primarily by the desire to secure the country's sea lanes to protect the flow of trade goods and energy resources. Some evidence suggests that the desire to enhance maritime power projection capability is also a motivating factor; however, given the modest pace of amphibious platform acquisition and the lack of supporting assets to facilitate operations in hostile littorals, the focus appears to be on the softer aspects of power projection rather than on the meaningful projection of hard military power ashore. Finally, there is very little support for the idea that concern about extraregional navies is driving Indian naval modernization as evidenced by the Navy's relative neglect of its submarine fleet.

Together, the ability to protect sea lanes and project soft maritime power across the region suggests that India is primarily focused on providing public goods that [39] can benefit all nations of the region in a manner befitting a regional hegemon. ${ }^{71}$ Like any pattern of behaviour, the trends exhibited over the past 20 years are not immune to exogenous shocks. For example, settlement of India's border disputes with Pakistan and China could finally allow the Navy the defence resources necessary to develop a true blue-water power projection fleet. Conversely, if China were to unexpectedly consolidate its maritime position in East Asia in a manner that allows it to redirect significant naval assets towards the Indian Ocean which requires resolving the Taiwan issue and establishing of a favourable naval balance visà-vis Japan and the US - the Indian Navy may be compelled to focus its energies on

\footnotetext{
${ }^{71}$ For literature on the hegemonic provision of public goods, see Charles Kindleberger, 'Dominance and Leadership in the International Economy: Exploitation, Public Goods and Free Rides', International Studies Quarterly, 25(2) (1981): 242-54; John G. Ikenberry, 'Rethinking the Origins of American Hegemony', Political Science Quarterly, 104(3) (1989).
} 
developing a robust sea-denial force. Apart from these kinds of significant geopolitical developments, however, the Indian Navy's medium-term priority will probably continue to be the development of a SLOC-defence, sea-control capability. [40] 
Figure 1: Indian Naval Strength: 1991-2011

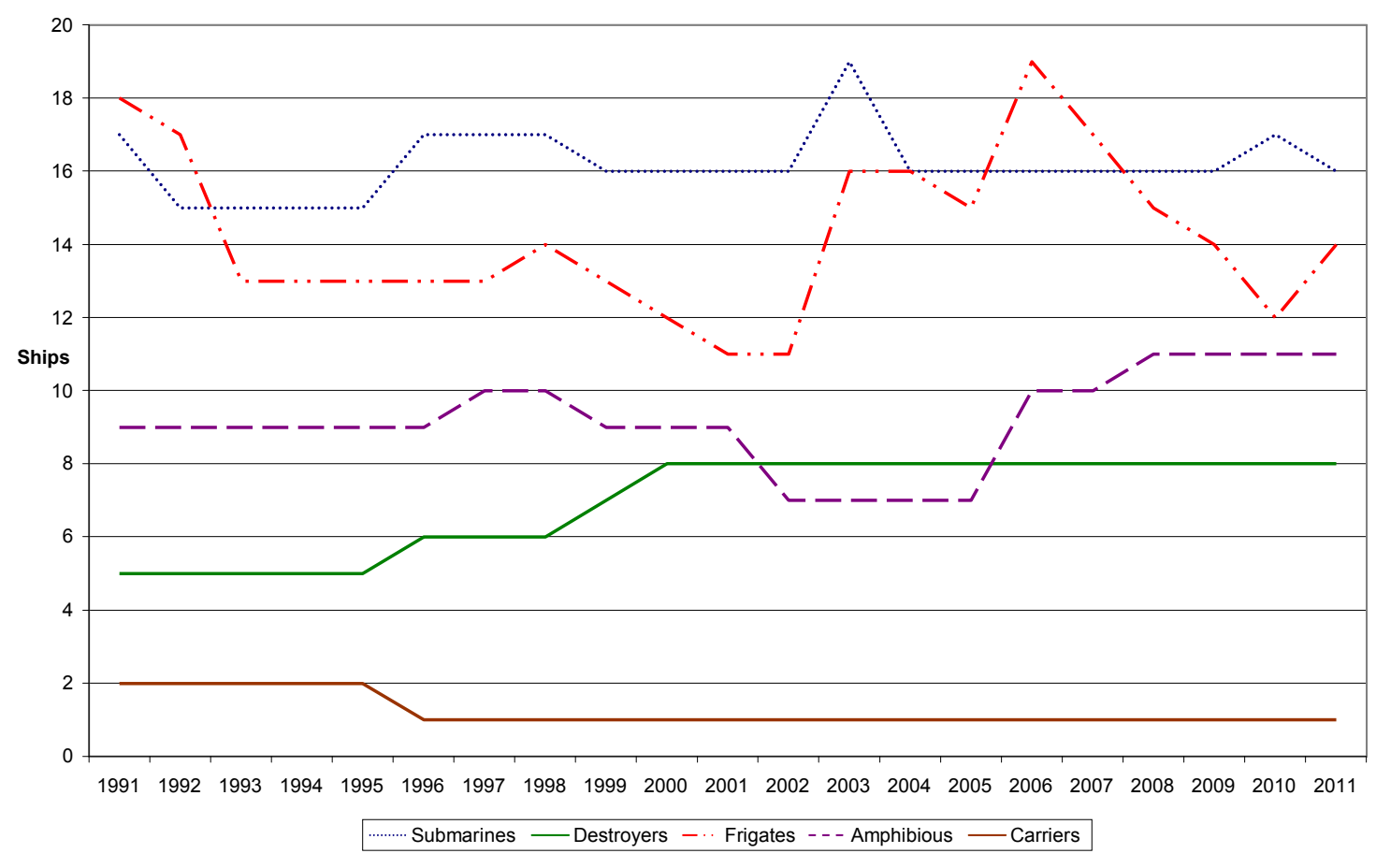


Figure 2: Naval Expenditure

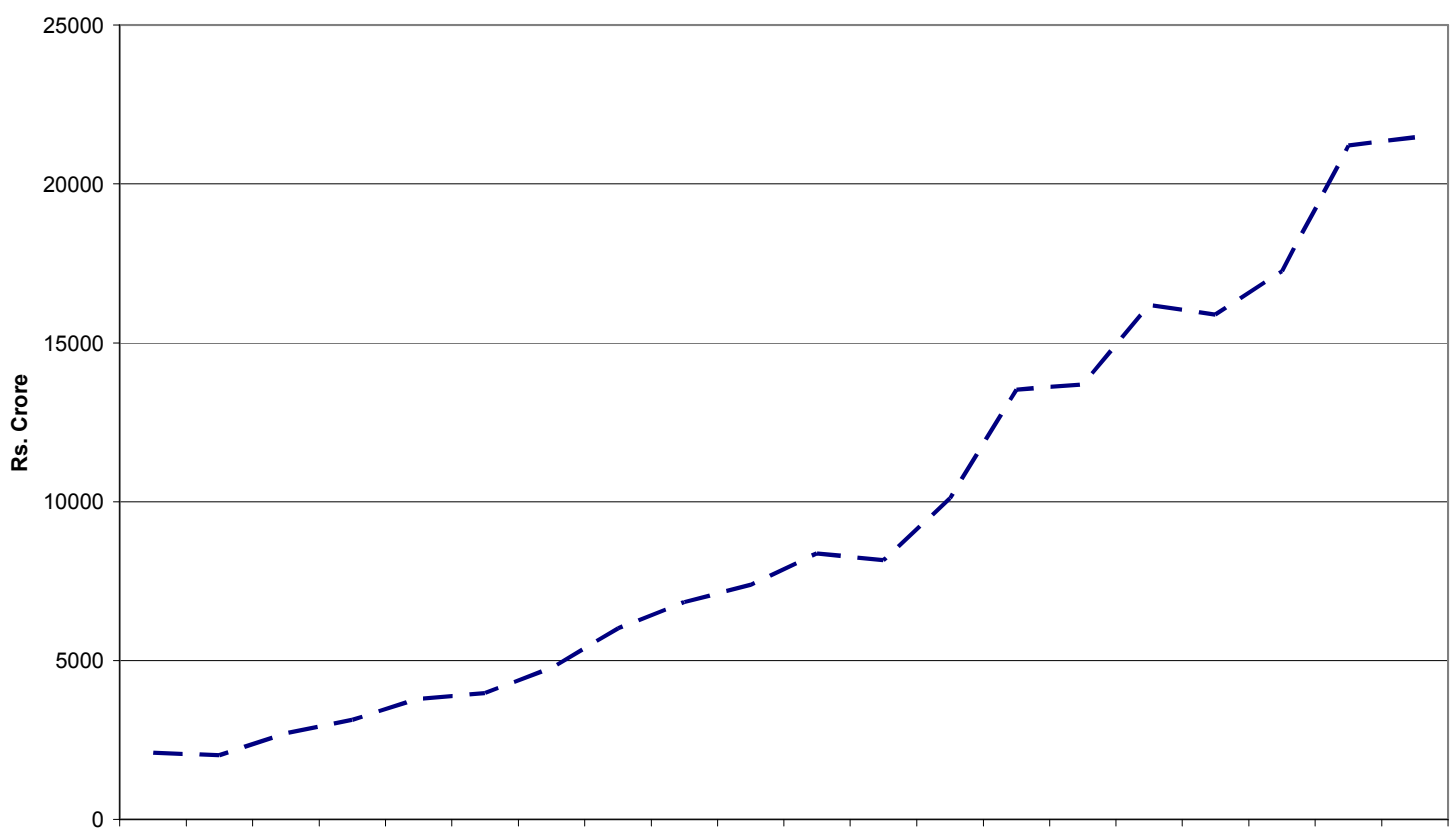

1991- 1992- 1993- 1994- 1995- 1996- 1997- 1998- 1999- 2000- 2001- 2002- 2003- 2004- 2005- 2006- 2007- 2008- 2009- 201019921993199419951996199719981999200020012002200320042005200620072008200920102011 
Figure 3: Total Defense Expenditure

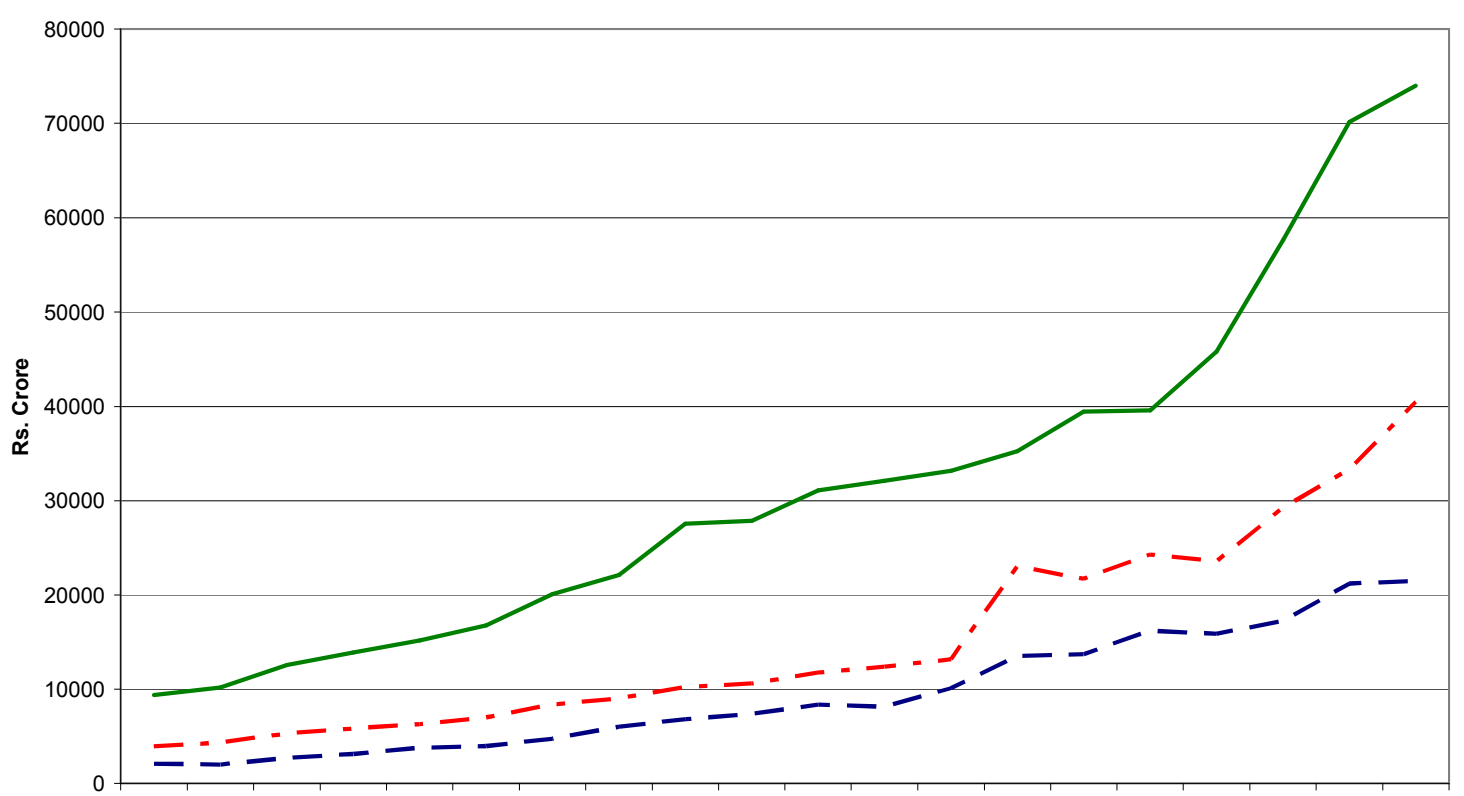

1991- 1992- 1993- 1994- 1995- 1996- 1997- 1998- 1999- 2000- 2001- 2002- 2003- 2004- 2005- 2006- 2007- 2008- 2009- 2010$\begin{array}{llllllllllllllllllll}1992 & 1993 & 1994 & 1995 & 1996 & 1997 & 1998 & 1999 & 2000 & 2001 & 2002 & 2003 & 2004 & 2005 & 2006 & 2007 & 2008 & 2009 & 2010 & 2011\end{array}$ - Army - - Navy - - Air Force 